\title{
生物多様性への貢献を主眼とした企業緑地評価ツール及び 簡易生物調査ツールの性能評価
}

\author{
岩㴊 翼 ${ }^{*}$. 増澤 直 $^{2}$. 三輪 隆 ${ }^{3}$. 小黒 芳生 ${ }^{4}$. \\ 横山 潤 $^{5} \cdot$ 中静 透 $^{4}$ \\ 1 東洋大学生命科学部 干 374-0113 群馬県邑楽郡板倉町泉野 1-1-1 \\ 2 株式会社地域環境計画 $\bar{\top} 154-0015$ 東京都世田谷区桜新町 2 丁目 22-3 NDS ビル 4F \\ ${ }^{3}$ 株式会社竹中工務店 技術研究所 $\bar{\top}$ 270-1395 千葉県印西市大塚 1-5-1 \\ 4 東北大学大学院生命科学研究科 $\overline{9} 980-8578$ 宮城県仙台市青葉区荒巻字青葉 6-3 \\ ${ }^{5}$ 山形大学理学部生物学科 $\bar{\top} 990-8560$ 山形県山形市小白川町1-4-12
}

\section{Evaluation of the tools for evaluating corporate green spaces and for simplified biodiversity survey \\ Tsubasa Iwabuchi $^{1^{*}}$, Tadashi Masuzawa ${ }^{2}$, Takashi Miwa ${ }^{3}$, Michio Oguro $^{4}$, Jun Yokoyama ${ }^{5}$, and Tohru Nakashizuka ${ }^{4}$}

\author{
${ }^{1}$ Faculty of Life Sciences, Toyo University, 1-1-1 Izumino, Itakura-cho, Gunma, 374-0113 Japan \\ ${ }^{2}$ Regional Environmental Planning Inc., NSS Building 4F, 2-22-3 Sakurashinmachi, Setagaya-ku, \\ Tokyo, 154-0015 Japan \\ ${ }^{3}$ Takenaka Research \& Development Institute, 1-5-1 Ohtsuka, Inzai, Chiba, 270-1395 Japan \\ ${ }^{4}$ Graduate School of Life Sciences, Tohoku University, 6-3 Aramaki-Aza-Aoba, Aoba-ku, Sendai, \\ Miyagi 980-8578 Japan \\ ${ }^{5}$ Department of Biology, Faculty of Science, Yamagata University, 1-4-12 Kojirakawa-machi, \\ Yamagata, Yamagata, 990-8560 Japan
}

\begin{abstract}
Green spaces at business sites potentially have important roles for biodiversity in urban ecosystems, where habitats of living organisms are greatly reduced and fragmented. Japan Business Initiative for Biodiversity (JBIB) has developed three tools consisting of the guideline that explains importance and methodology of land use for biodiversity, the land use score card that quantitatively evaluates land use, and the monitoring sheet, with which non-experts can conduct a biodiversity survey. Although these tools were developed based on ecological knowledge, it was necessary to separately evaluate whether a site with high land use score actually have high biodiversity, and how reliable the data obtained by a survey by non-experts with the monitoring sheet is. Here, we conducted biodiversity surveys by non-experts with the monitoring sheet and by experts at the same time and date at eight business sites and compared the data obtained by the two survey methods. As a result, there were positive correlations between the land use scores and $\alpha$-diversity, and between the $\alpha$-diversities and also the $\beta$-diversities of the non-expert and the expert surveys. These results, as far as for evaluating overall biotas by $\alpha$-diversity and $\beta$-diversity, validate the tools to promote land use for biodiversity enhancement at business sites.
\end{abstract}

Key Words: Green space at business site, Land use evaluation for biodiversity, Biodiversity survey, Citizen science, Urban ecosystem

\footnotetext{
*連絡先 : iwa283@gmail.com

受付 : 2014 年 1 月 8 日/受理 : 2014 年 5 月 24 日
} 
要旨 : 生物の生息域が大きく縮小・分断化された都市域生態系では，企業緑地が重要な役割を果たす可能性がある．企業と生物多様 性イニシアティブ（JBIB）は，地域の生物多様性に貢献できる企業緑地を推進するために，生物多様性に貢献する土地利用を推進す

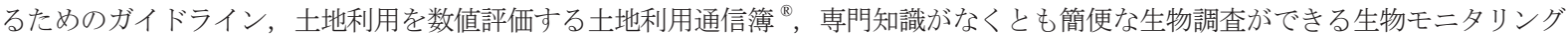
シートの 3 つのツルを開発した。 これらのツールは生態学の知見を基に作られているものの, 通信簿で高得点の緑地は実際に生物 多様性が高いのか，非専門家がモニタリングシートを用いて得た調査データはどの程度の質・信頼性を持つのか，という 2 点は別途， 検証する必要があった. 今回, 業種の異なる 5 社に協力してもらい, 全国 8 事業所において専門知識のない事業所の社員によるモニ タリングシートを使った調查と，環境調查会社の生物専門家による調査を同日・同時間帯に実施し，得られたデータを比較した。 そ の結果，通信簿点数と $\alpha$ 多様性，また社員による調查と専門家による調査の $\alpha$ 多様性および $\beta$ 多様性の間にはそれぞれ正の相関関 係があることが明らかとなり， $\alpha$ 多様性や $\beta$ 多様性といった生物相の概況を評価する上では，地域の生物多様性に貢献する企業所有 地の土地利用を推進するツールとしての妥当性が確認された. キーワード : 企業緑地，土地利用評価，生物調査，市民調査，都市生態系

\section{はじめに}

国際連合の報告によれば，都市域で生活する人々 の数が 2008 年に世界人口の 5 割を越えた（UNPD 2007)。特に先進国では農村地域の人口が過疎化や高 齢化により減り続けており，人々の都市部への集中 化は今後さらに顕著になるだろう。人間活動は様々 な形で生物の生息地を消失させているが（Czech et al. 2000)，中でも都市開発は，最大規模の地域絶滅を引 き起こし，在来種の大部分を排除してしまうことが 多い（Luniak 1994 ; Marzluff 2001)。都市は，一般に 起伏の小さい平野に発達することが多いため, 汇濫 原や低地性の緑地などの特定の環境を殊に減少させ ている（森本 2011）。それは地域の生態系の多様性を 減少させることに他ならず，環境変化に対する地域 全体の頑健性も損なわれていると考えられる（Mougi and Kondoh 2012 ; 宮下ほか 2012)．生物多様性の回復 のためには，大面積の緑地を確保することが重要だ が（Arrhenius 1921），小規模なものであっても，生物 の移動を促す「飛び石」や「コリドー (回廊)」の役 割を持つ可能性がある（Fischer and Lindenmayer 2002 ;

Haddad et al. 2003 ; Schultz 1998 ; Murphy and LovettDoust 2004）。また，小規模であっても特徴の異なる 保護区を複数設置することによって多様性に富むマ トリックスが形成され，多くの個体群を維持できる 可能性もある（Baum et al. 2004 ; Prevedello and Vieira 2010)。公園などの公的緑地にはそうした役割が期待 されるが，都市部で大きな面積を占める企業敷地内 の緑地もあわせた取り組みを進めることで，保全の 効果をより高めることができるだろう。しかし，都 市生態系における生物多様性保全を目的亡して企業 緑地に焦点を当てた研究は，公園や社寺林に関する 研究に比べて非常に少ない。

企業敷地内の緑地は，工場緑地法などの法整備な どにより, 絶対量としてはかなりの面積に達する. 工場の緑地面積は全国で $350 \mathrm{~km}^{2}$ を超え，環境施設面
積を含めるとおよそ $650 \mathrm{~km}^{2}$ にもなる（経済産業省地 域経済産業グループ立地環境整備課 2012). しかしこ れらの緑地のほとんどは, 緑地の絶対量の確保にの み焦点があり，いかに緑化や維持に必要なコストを 抑えるかといったことが優先事項となっている（増 澤 2010). そのため，外来植物が導入されていたり， 緑地が分断化あるいは辺縁部に薄く（樹木が 1 列に 並ぶなど）配置されていたりと，生物の利用場所と しての機能を発揮しているとは言い難い緑地が多い. しかし一方で，企業緑地は公園などのように行政手 続を経る必要がないため, 企業単独の判断で手を加 えることができるという利点がある，さらに，公園 や社寺よりも人の出入りが少ないため, 人為的摚乱 が小さいという強みもある。このように，企業敷地 内の緑地には，公的緑地にはないメリットがあり， その有効活用が期待される.

ここ数年, 生物多様性条約第 10 回締約国会議 （COP10）を名古屋で開催したことなどによる関心の高 まりや，企業活動の持続性を考える上で生物多様性の 重要性が存在感を増してきたことにより, 生物多様性 の保全に積極的に取り組む企業の数は増加傾向にあ る．そうした状況を受けて「企業と生物多様性イニシ アティブ (JBIB)」は, 東北大学と協力して企業敷地 の土地利用，とくに緑地のあり方を改善し，地域の生 物多様性に貢献寸るための「いきもの共生事業所 ${ }^{\circledR}$ 推 進ツール 3 点セット」を開発した（三輪 2011）。3つの ツールのうち 1 つ目は「いきもの共生事業所 ${ }^{\circledR}$ 推進ガ イドライン」と呼ばれ，企業緑地において生物多様性 に配慮した土地利用や緑地作りに取り組む意義やその 指針について解説している．2つ目は「土地利用通信 簿 ${ }^{\circledR} 」$ と呼ばれ，地域の生物多様性への貢献という観 点から企業緑地を 0-100 点で数值評価するツールと なっており, 緑地そのものを生態学的な知見に基づい て評価する項目と, 企業の取り組み内容を評価する項 目を合わせた 17 項目で構成されている. 3 つ目の生物 モニタリングシートは，実際にどのような生物が緑地 
を利用しているのかということについて，専門知識が なくとも社員自らが生物調査を実施できるようにデザ インされた生物調査ツールである.これら 3 つのツー ルはすでに数十の企業が利用しており，いきもの共生 事業所 ${ }^{\circledR}$ 推進 Web（http://www.blunc.org）や講習会を通 じてより幅広い普及が図られている。

生物多様性に貢献する環境を評価するツールは既に いくつか開発されているが，その評価と実際の生物多 様性の関連性が検証されたツールはほとんどない。そ こで本研究では, 土地利用通信簿 ${ }^{\circledR}$ の点数が高いほど 生物多様性は高くなるのか（課題(1)，生物モニタリ ングシートを用いた非専門家による調査でどの程度生 物相が把握できるのか（課題(2)， という2つを検証・
評価するため, 中部地方から九州地方にかけて合計 8 事業所において土地利用通信簿 ${ }^{\circledR}$ による採点および生 物調査を行い, ツールの性能と妥当性を評価した。

\section{調査地および方法}

\section{1. 評価に用いたツール}

本研究では, 上記の 3 つのツールのうち,「土地利

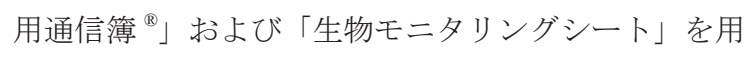
いて, 企業緑地内の生物多様性のレベルの把握に, これらツールが有効かどうかを検証した。

土地利用通信簿 ${ }^{\circledR}$ は大きく 3 パートからなる (表 1 ). パート 1 は, 生物多様性に貢献する環境づくりを評

表 1. 土地利用通信簿 ${ }^{\circledR}$ の評価項目と配点

\begin{tabular}{|c|c|c|c|c|}
\hline & $\begin{array}{l}\text { 項目 } \\
\text { 番号 }\end{array}$ & 項目名 & 評価内容 & 配点 \\
\hline 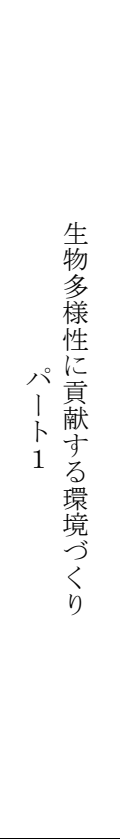 & $\begin{array}{l}1 \\
2\end{array}$ & $\begin{array}{l}\text { 生物多様性に貢献する面積 } \\
\text { の大きさ } \\
\text { 緑の構造 } \\
\text { 2-1 樹林の高さと階層構造 } \\
\text { 2-2 樹林-草地の連続性 } \\
\text { 2-3 草地・芝地の構造 } \\
\text { 2-4 水辺の構造 } \\
\text { まとまりのある緑地作り } \\
\text { 植生を支える土壇の厚みと } \\
\text { 土質 } \\
\text { 周辺環境との調和（生態系ネ } \\
\text { ットクの創出） } \\
\text { 地域に根ざした植生の創出 } \\
\text { 生物多様性に貢献する質の } \\
\text { 高い屋上や壁面の緑地の創 } \\
\text { 出 } \\
\text { 動物の生息場所や移動経路 } \\
\text { に対する配慮 }\end{array}$ & $\begin{array}{l}\text { 敷地内の樹林・草地の他, 屋上緑化, 水 } \\
\text { 面, 非舗装面が占める割合 } \\
\text { 樹林の高さ, 階層構造をなす要素の有無 } \\
\text { (高木層, 低木層, 草本層) } \\
\text { 樹林から草地へのエコトーンの変化とそ } \\
\text { の幅 } \\
\text { 種構成, 刈高 } \\
\text { 水辺の護岸方法, 抽水植物の有無 } \\
\text { 敷地内に一つの塊として存在する緑地の } \\
\text { 面積 } \\
\text { 地盤の種類, 人工地盤ではその厚さ } \\
\text { 周辺地域の自然環境や成り立ちに関する } \\
\text { 調査に基づいた緑地設計・管理 } \\
\text { 樹木や草本の地域性（地域性種苗, 在来 } \\
\text { 種, 外来種） } \\
\text { 屋上緑化の立体性, 植生の種構成 } \\
\text { 小川の蛇行化や排水溝の緩斜面化など生 } \\
\text { 物の生息や移動に配慮した取組 }\end{array}$ & $\begin{array}{l}3 \\
5\end{array}$ \\
\hline 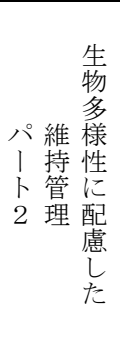 & $\begin{array}{l}12 \\
13\end{array}$ & $\begin{array}{l}\text { 化学物質の適切な管理 } \\
\text { 水循環への配慮 } \\
\text { 物質循環への配慮 } \\
\text { 指標生物のモニタリングの } \\
\text { 活用 } \\
\text { 外来生物に対する対策 }\end{array}$ & $\begin{array}{l}\text { 化学肥料・除草剤・殺虫剤等化学薬品の } \\
\text { 使用頻度・方法 } \\
\text { 貯水槽, 透水性舗装の使用など雨水の有 } \\
\text { 効利用や地下水涵養に配慮した水管理 } \\
\text { コンポスト化や落葉・落枝の自然分解な } \\
\text { ど発生材の利用 } \\
\text { 緑地を利用する生物の調査の頻度と内 } \\
\text { 容, およ管理・設計への活用 } \\
\text { 外来生物に対する管理ルール・駆除 }\end{array}$ & $\begin{array}{c}10 \\
3\end{array}$ \\
\hline 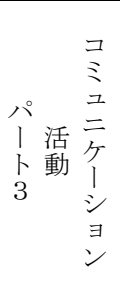 & 16 & $\begin{array}{l}\text { 地域及び専門家との連携 } \\
\text { 事業所における人材の育成 } \\
\text { と配置 } \\
\text { 社員の参画 } \\
\text { 社外向けの環境教育プログ } \\
\text { ラムの推進 }\end{array}$ & $\begin{array}{l}\text { 地域のステークホルダーとの連携した取 } \\
\text { 組の実施 } \\
\text { 生物多様性への貢献を推進する人材の育 } \\
\text { 成と配置 } \\
\text { 事業所の緑地を利用した社員向け環境教 } \\
\text { 育の実施 } \\
\text { 事業所の緑地を利用した社外向けの環境 } \\
\text { 教育の実施 }\end{array}$ & 3 \\
\hline \multicolumn{4}{|c|}{$\begin{array}{ll}\text { 合 } & \text { 計 }\end{array}$} & 100 \\
\hline
\end{tabular}


価する. 項目 1 〜 3 では緑地の面積だけでなく, そ の階層構造や連続性, 形状を評価しており, より複 雑で多様な環境を持つ緑地ほど高得点になる。 また 項目 5 〜 8 では緑地の基盤となる土壤の評価や, 生 態系ネットワークや地域植生への寄与などの評価を 行う。パート 2 は生物多様性に配慮した維持管理に ついて評価する. 農薬・肥料などの化学物質の使用 や水・物質の循環への配慮の取り組み, 外来種対策 などが含まれる。パート 3 にはコミュニケーション 活動として, 地域連携や人材育成などの協力関係や 普及啓発に関する評価項目が含まれる。これらの合 計 17 項目により緑地を多角的に評価することで，緑 地の現状だけでなく, 維持能力や将来性も評価に取 り入れていることがこのツールの特徵である. より 詳しい採点基準等については，冊子体の「いきもの 共生事業所 ${ }^{\circledR}$ 推進ガイドライン」(企業と生物多様性 イニシアティブ 2012）を参照して頂きたい.

生物モニタリングシートは, サイズや色などの形 質や指標する環境が近い生物種を「種群」に分け, その種群の在不在を記録するように作られている（表 2 ; 種名左の灰色の部分). 種群の分け方は, 専門知 識のない人でも調査できるように見分けやすさを重 視している，例えば，キツツキはサイズにより大型 と小型の 2 つ種群に分かれている. 小型のキツツ キに含まれる種は主にコゲラであり，この種は他種 に比べ都市近隣の小規模な森林にも生息するといっ た生態学的特徵も持つため, 小型か大型かによって 森林の規模や特徵を指標することを想定している. また，モンシロチョウとキタキチョウのように，分 類群としては近いが色によって区別した種群や，「町 でよく見る鳥」としてスズメやカラスを一群にまと めるなど生息環境を重視した種群もある。ただしほ とんどの分け方は機能群や分類群による分け方に順 じている（表 2). また, 実際の調査時の状況を考慮 して, 昆虫類のように比較的近距離で確認できる生 物は分け方をより細かく（主に科レベル，鳥類のよ うに比較的遠距離でしか観察できない生物では分け 方をより粗く（主に目レベル）している。こうした 工夫よって, 生物モニタリングシートは専門知識が なくても生物を分類することができ，また種レベル の把握はできなくても生物の利用環境として指標と なる生物の組成が把握できるようにデザインされて いる（企業と生物多様性イニシアティブ 2012）.

\section{2. 調査の概要}

本研究で実施した調査で得られたデータセットは 次の 3 つである：(1) 土地利用通信簿 ${ }^{\circledR} の$ 点数，（2） 事業所の社員（生物の専門的教育を受けていない） によるモニタリングシートを使った生物調査結果（以 下, 社員調査), (3) 生物調査の専門家による生物調 査結果 (以下, 専門家調查)。社員調査と専門家調査は, 同じ調査地点で同日・同時間帯に実施した。これら の結果から, 課題(1)を評価するために, 通信簿の点 数と $\alpha$ 多様性との関係を社員調査および専門家調查 の両方で調べた。 また, 課題(2)を評価するために, $\alpha$ 多様性および $\beta$ 多様性（群集非類似度）について専 門家調査の結果と社員調査の結果を比較した。社員 と専門家では調查スキルが異なる上に, 後述のとお り社員調査と専門家調査では調査人数が異なってい るため, 本研究では社員調査の結果と専門家調査の 結果で $\alpha$ 多様性および $\beta$ 多様性の絶対值が一致する かどうかではなく, 相関関係が見られるかどうかで 評価した。

\section{3. 調査地・調査日}

JBIB の会員企業に協力を募り, 最終的には 5 社か らの協力を得て合計 8 事業所で調査を行った（表 3). 5 社の業種には食品・化学・印刷などが含まれ, 各事 業所は工場または研究施設であった。調査は 2012 年 8 月 7 日から 10 月 4 日にかけて実施した.

生物調査では, 調查対象の 1 事業所女たり 3 つの 調查地点を設定した. そのうち2つは事業所の敷地 内にある緑地とし, 残りの 1 つは地域で生物多様性 のソースとなる緑地（ソース緑地）として, 事業所 からおよそ $2 \mathrm{~km}$ 以内にある公園や神社を選んだ.ソー ス緑地には, 著者がインターネットで候補地を選定 して事前に現地を下見することにより，草地や森林， 水辺など多様な生息環境が混在し, かつ生物の種数 が多く見られた緑地を選んだ。各調査地点は，「ひと かたまり」の緑地を 1 地点とした. ほとんどの調查 地点は周囲が道路や建造物で区切られており, サイ ズはおよそ 30 〜 50 メートル四方であった. これは 各調査員が調查範囲を少なくとも 1 回は時間内に周 回できるサイズである.また後述のとおり各地点で の調査は時間が限られており, 生物相の正確な把握 には不十分だった可能性があるが，それによるデー タのバラつきを抑えるため, より多くの地点を調查 した. 今回は 8 つの事業所それぞれで 3 地点の調査 を行ったため, 合計 24 地点で社員調查と専門家調查 


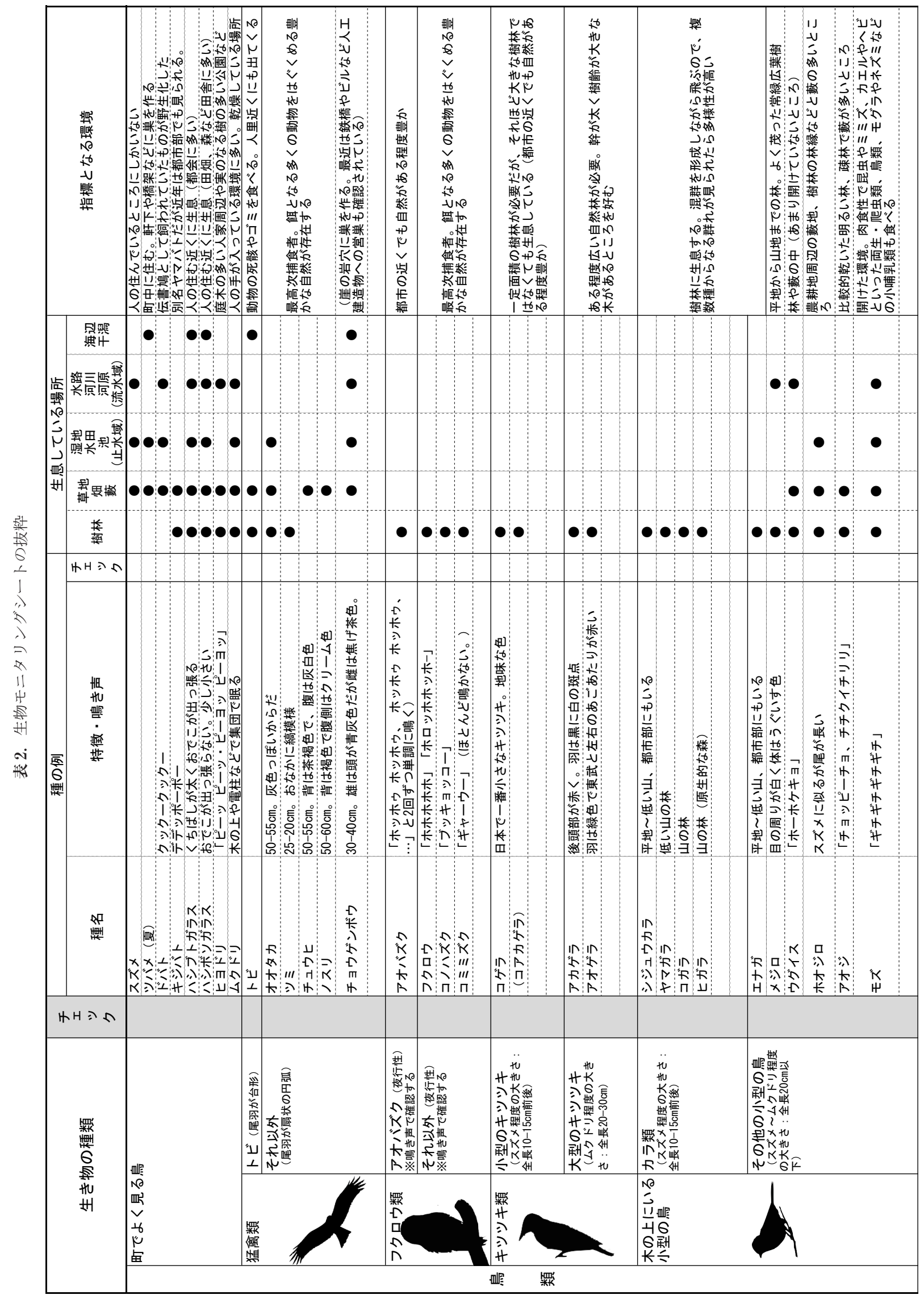




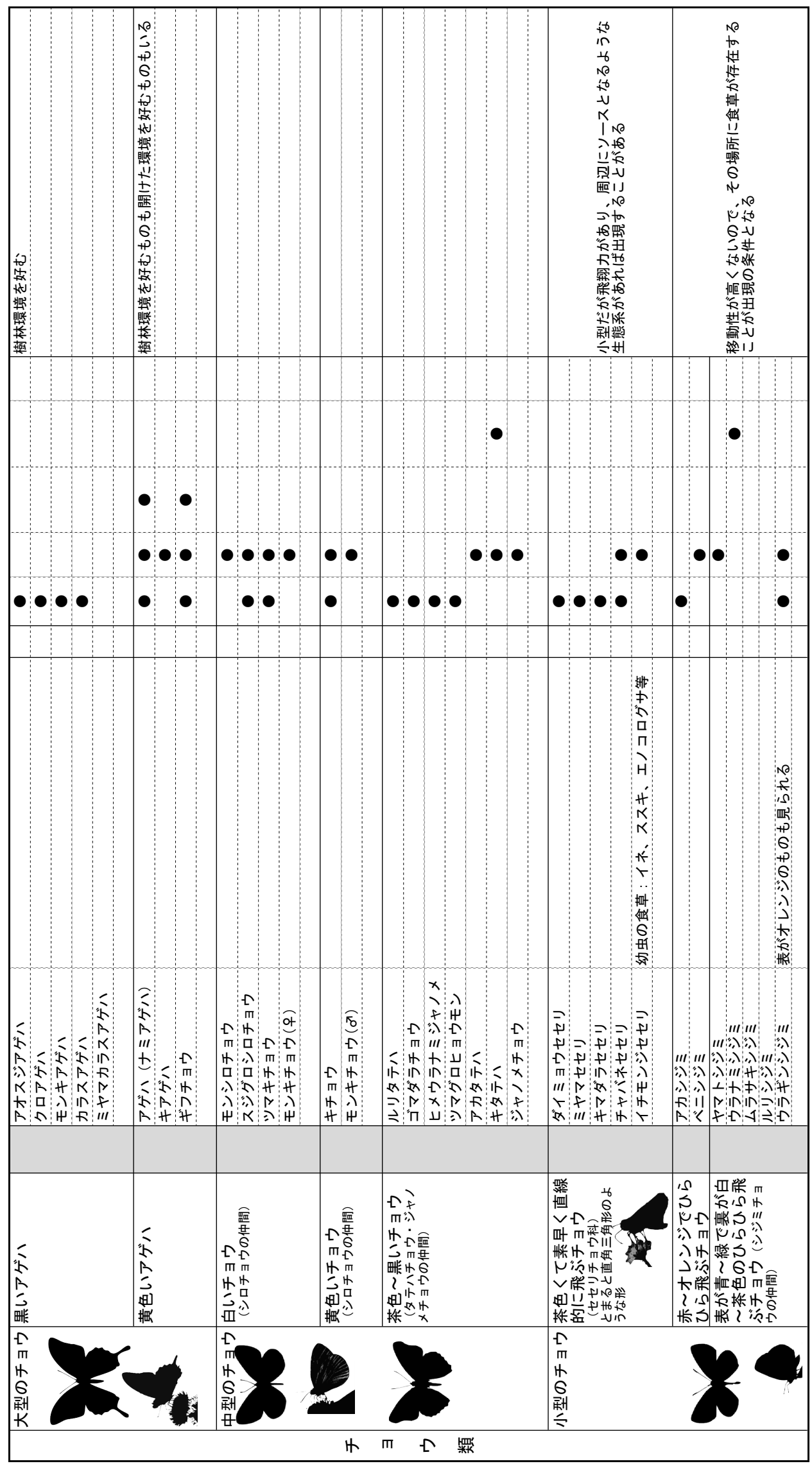


を行ったことになる.

\section{4. 調査手順}

社員調査では，各事業所でそれぞれ招集してもらつ た $8 \sim 12$ 名の社員を調査員とした。各社員は生物に 対する興味や知識は様々で調査能力にも差異がある と予想されたことから，調査スキルの個人差による 調査結果のばらつきを抑えるために複数人数で調査 することにした，事前に行った予備調査の結果を用 いて，ランダムサンプリングによる調査人数と発見 種群数の関係をシミュレーションしたところ， 8 人以 上では種群数がほぼ飽和していた（岩㴊・小黒未発 表). 一方で人数が増えると, それだけの人数社員を 招集することが困難になること，また踏みつけなど の撹乱が大きくなることから，ここでは 12 人を上限 とした．実際の調査では，一人ひとりにモニタリン グシートを持たせて調査対象地を 15 分間自由に歩い てもらい，見つけた生物が当てはまる種群にチェッ クを入れてもらった. 誤認を極力減らすために, 調 査開始前には必ず事前講習を行い, 各種群の特徴や 見分け方について説明した。専門家調查は，(株地域 環境計画に依頼して調査員を派遣してもらい実施し た．各調査地において鳥の調查員 1 名・昆虫および 地上徘徊性生物の調査員 2 名が，15 分間に見つけた 生物の種名と個体数を記録した。個体数が多すぎて 計数が不可能な場合は「多」として記録した。事業 所あたり 3 地点で生物調查を実施したため, 社員調 査を調查地 $1 \rightarrow 2 \rightarrow 3$ の順に行い，専門家調查を調 査地 $3 \rightarrow 1 \rightarrow 2$ の順に行うことで，2つの調査チーム が同じ時間帯に独立した調査を実施することができ た.

\section{5. 土地被覆率の算出}

各調査地点で見られた生物は，周辺の土地利用に 影響されることが考えられるため, 調查地点から半 径 $1 \mathrm{~km}$ の円内の土地被覆率を ArcGIS 10.0（ESRI 社） を用いて算出した。 土地被覆は, 環境省自然環境保 全基礎調査・第 $6 \sim 7$ 回植生調查の 2 万 5 千分の 1 現存植生図によって算出した。 その際, 植生区分を 緑地, 市街地, 公園・農地, 水面の 4 カテゴリのい ずれかに振り分けて, 各カテゴリの被覆率を算出し た.ここでは植林地を含む森林や草原を緑地として 定義した。事業所周辺の土地利用は, 緑地が 5 割を 超えるものから市街地が 9 割を超えるものまで様々 であった（表 3).また周辺土地利用の非類似度とし て 4 カテゴリの被覆率から地点間の Bray-Curtis 非類 似度 $\left(d_{B C}\right)$ を次式より算出した.

$$
d_{B C}=\frac{\sum_{k=0}^{n-1}\left|y_{i, k}-y_{j, k}\right|}{\sum_{k=0}^{n-1}\left(y_{i, k}+y_{j, k}\right)}
$$

y は各土地利用カテゴリ（k）の被覆率, $\mathrm{n}$ はカテゴ リ数、 $\mathrm{i}$ および $\mathrm{j}$ は比較する任意の 2 地点を表す.

\section{6. 解析方法}

通信簿の点数は上限（100 点）があることから， 0-1 スケールに変換後, アークサイン変換した．また 土地被覆率も同様にアークサイン変換した值を解析 に用いた，社員調查で得られるのは，調查員ごとの モニタリングシートの各種群の在不在データである. したがって社員調査における $\alpha$ 多様性は「種群数」を, $\beta$ 多様性は各種群の在不在データから算出される地点 間の群集非類似度（Jaccard 指数， $d_{J}$ ) を指す（式 2).

表 3. 調查事業所の概要

通信簿点数は, 土地利用通信簿 ${ }^{\circledR}$ の合計点数を表す。平均気温は調査地点か ら最も近い気象庁の気象観測所における調査時間中の平均気温を表す.

\begin{tabular}{|c|c|c|c|c|c|c|c|c|c|c|c|c|}
\hline \multirow[b]{2}{*}{ 所有地 } & \multirow[b]{2}{*}{$\begin{array}{c}\text { 面積 } \\
\left(\times 10,000 \mathrm{~m}^{2}\right)\end{array}$} & \multicolumn{3}{|l|}{ 事業所 } & \multicolumn{4}{|c|}{$\begin{array}{l}\text { 周辺土地利用内訳 } \\
(\%, \text { 半径 } 1 \mathrm{~km} \text { 以内 })\end{array}$} & \multirow{2}{*}{$\begin{array}{l}\text { 調査日 } \\
2012 \text { 年 }\end{array}$} & \multirow{2}{*}{$\begin{array}{l}\text { 平均 } \\
\text { 気温. }\end{array}$} & \multirow{2}{*}{$\begin{array}{c}\text { 社員調査 } \\
\text { 人数 }\end{array}$} & \multirow{2}{*}{$\begin{array}{c}\text { 事業所外 } \\
\text { 調査地 }\end{array}$} \\
\hline & & $\begin{array}{c}\text { 緑地率 } \\
(\%)\end{array}$ & 緑地の概要 & $\begin{array}{l}\text { 通信簿 } \\
\text { 点数 }\end{array}$ & 緑地 & $\begin{array}{l}\text { 公園· } \\
\text { 農地 }\end{array}$ & 市街地 & 水面 & & & & \\
\hline 茨木市 & 5.6 & 48.8 & 二次林, 芝地 & 62 & 3.8 & 27.7 & 66.0 & 2.5 & $8 / 31$ & 32.1 & 10 & 公園 \\
\hline 岩国市 & 52.0 & 19. 7 & 疎林, ため池 & 56 & 0.1 & 9.9 & 65.1 & 24.9 & $8 / 7$ & 31.5 & 10 & 公園 \\
\hline 岡山市 & 18.0 & 21.4 & 草地, 疎林 & 38 & 63.0 & 25.9 & 10.2 & 0.9 & $9 / 11$ & 24.7 & 12 & 神社 \\
\hline 佐賀市 & 22.4 & 20.2 & 疎林，クリーク & 28 & 0.6 & 47.7 & 39.1 & 12.6 & $8 / 21$ & 30.7 & 9 & 神社 \\
\hline 名古屋市 & 5.9 & 22.3 & 大半が芝地 & 25 & 8.7 & 8.6 & 75.1 & 7.7 & $9 / 14$ & 29.5 & 9 & 河川敷 \\
\hline 富士市 & 57.4 & 41.2 & 二次林, ため池 & 91 & 4. 3 & 28.9 & 52.5 & 14.3 & $10 / 4$ & 26.5 & 9 & 公園 \\
\hline 守山市 & 31.1 & 26.9 & 草地，疎林 & 37 & 8.5 & 27.6 & 61.4 & 2.5 & $9 / 19$ & 28.2 & 8 & 河川敷 \\
\hline 四日市市 & 62.8 & 10.1 & 二次林, クリーク & 28 & 0.3 & 4.2 & 94.8 & 0.8 & $9 / 7$ & 29.5 & 9 & 公園 \\
\hline
\end{tabular}




$$
d_{J}=\frac{S_{i 0}+S_{0 j}}{S_{i 0}+S_{0 j}+S_{i j}}
$$

$S_{i 0}$ は調査地 $i$ のみで見つかった種数， $S_{0 j}$ は調査地 $j$ の みで見つかった種数， $S_{i j}$ は調査地 $i$ と $j$ の両方で見つ かった種数を表す，専門家調查では各種の個体数デー 夕を得た。したがって専門家調査における $\alpha$ 多様性 は種数を指している. $\beta$ 多様性では, 社員調査の $\beta$ 多 様性指標と評価単位を揃えるため, 個体数データを 在不在データに変換してから算出した群集非類似度 （Jaccard 指数）を用いた。

まず課題(1)を検証するために，応答変数を種群数 (社員調查）または種数（専門家調查）とした一般化 線形混合モデル（GLMM，ポアソン分布）を用いた モデル選択を行った。固定効果には土地利用通信簿 ${ }^{\circledR}$ の点数，土地被覆率，気温を用いた。 ランダム効果 には事業所と調査員（社員調査のみ）を入れた。調 査日は事業所ごとに分けられているため, 省略した. モデル選択は，総当りによる AIC 比較を行い，AIC が最小のモデルからの $\Delta \mathrm{AIC}$ が 2 以下のモデルを採択 モデルとした．採択モデルが複数ある場合は，全採 択モデルに共通する説明変数を採択されたものとみ なした。ただし，採択された説明変数間に多重共線 性が疑われた場合（ここではVIF 值 10 以上とした） には，その説明変数を除外して再度モデル選択を実 施した。

課題(2)を検証するため，専門家調査の総発見種数 を応答変数, 社員調査の総発見種群数を固定効果, 事業所をランダム効果とした GLMM（ポアソン分布） を用いたモデル選択を行った．次に，調査地点間の 群集非類似度（Jaccard 指数）を社員調査および専門

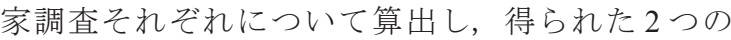
Jaccard 指数どうしの相関を調べるために，マンテル 検定を行った（9999 回試行）。さらに，社員調査また は専門家調査の群集非類似度と土地利用通信簿 ${ }^{\circledR}$ の点 差との相関を調べるために，地理的距離および周辺 土地利用の非類似度（Bray-Curtis 指数）の影響を制御 した偏マンテル検定を行った（9999回試行）。

生物調査の専門家と，専門知識の無い社員では, 調査スキルに大きな違いがあるはずである。生物の 見つけやすさや判別しやすさによってその違いの大 小は異なると予想された。 そこで，今回の生物モ二 タリングシートを使った調査でスキルの差がどのよ うに現れるのかを明らかにするため，調査データか ら記録数の多かった鳥類と昆虫類に対象を絞り $\alpha$ 多
様性の違いを検証した。具体的には，鳥類および昆 虫類それぞれの社員調査の種群数と, 専門家調査の 種数をモニタリングシートの分け方にならって種群 に分け直して得た種群数との違い調べるために尤度 比検定を行った。

また，社員調査では各調査員は在不在データしか 取らないが，同じ場所を複数人で調査するため，発 見率を生物量（個体数）の指標として利用出来る可 能性がある。これを検証するため, まず専門家調査 のデータをモニタリングシートの分類に合わせて種 群に振り分け，同じ種群の個体数の和を各種群の個 体数とした．個体数が多く計数が不可能だったため 「多」と記録した種群はこの解析からは除外した。こ のデータセットと社員調査の各種群の発見率（アー クサイン変換した值）との相関を，ピアソンの積率 相関係数に対する $\mathrm{t}$ 検定により調べた。

解析は全て R 3.01 (R Development Core Team 2013) を用いて行った。なお，土地利用通信簿 ${ }^{\circledR}$ の評点項目 のうち, パート 3 の評価項目は, 将来的に生物多様 性に貢献する可能性はあるが, 調査時点での緑地や 生物多様性に直接寄与寸るとは考えにくい，そのた め，土地利用通信簿 ${ }^{\circledR}$ の総点からパート 3 の点数を差 し引いた点数を用いて上記の一連の解析を行ったが， 結果に大きな違いは見られなかった。 そのため以降 ではパート 3 の点数を含めた総点での結果を示す.

\section{結果}

\section{1. 調査結果の概要}

社員調査では，延べ 76 名の社員が調査を行い，モ ニタリングシートのチェックの総数, 寸なわち総記 録回数は 2598 回に上った. 1 回以上記録された種群 数は 71 で, そのうち鳥類が 14 , 昆虫類は 36 , クモ類 2, 土壤動物 5, 爬虫類 3, 両生類 3, 軟体動物 2, 魚 類 3, その他の水生動物 6 であった。一方専門家調查 では，延べ3000 個体以上が記録された。総種数は 233 種類で，そのうち鳥類が 39, 昆虫類が 176, クモ 類 8 , 土壤動物 1 , 爬虫類 3 , 両生類 4 , 魚類 1 , 哺乳 類 1 であった. 各調査地点の発見種数および種群数 を図 1 に示す. ソース緑地よりも事業所敷地内の緑 地の方が種数・種群数が多かった事業所もあった.

\section{2. 土地利用通信簿 ${ }^{\circledR}$ 発見種数 - 種群数の関係}

土地利用通信簿 ${ }^{\circledR} の$ 点数と発見種群数（社員調査） または発見種数（専門家調査）の関係を図 2 に示す。 
GLMM のモデル選択の結果，選択されたモデルのほ ぼ全てにおいて通信簿の点数が有意な正の固定効果 として入っており，モデルの説明率は $50 \%$ 前後だっ た（表 4, 表 5)。これらのことから, 社員調査でも 専門家調査でも土地利用通信簿 ${ }^{\circledR}$ の点数が高くなるほ ど $\alpha$ 多様性が高くなることが示唆された.

\section{3. 社員調査と専門家調査の関係}

\section{(1) $\alpha$ 多様性}

社員調査の発見種群数と専門家調査の発見種数の 関係についてモデル選択を行った結果，社員調査の 発見種群数と専門家調査の発見種数との間には有意 な正の関係が見られた。モデルによる逸脱度の説明 率は $28.2 \%$ だった。これらの結果から, 社員調查で種 群数が多かった調查地は, 専門家調查でも種数が多 かったことが示された（表 6).

\section{（2） $\beta$ 多様性}

社員調査と専門家調査の群集非類似度（Jaccard 指 数）の関係を図 3 に示す. マンテル検定の結果, 両 者には正の関係が認められた（マンテル相関係数 0.38 , $\mathrm{p}<0.05)$. このことは，群集非類似度においても社員 調査でも専門家調査と同様の傾向を持つ調査データ が得られていたことを示唆する。また，土地利用の 非類似度と地理的距離の影響を制御した偏マンテル 検定の結果，通信簿の点差と群集非類似度との間に は社員調査でも専門家調査でも正の関係が見られた (社員調查 : 偏相関係数 $0.32, \mathrm{p}<0.05$; 専門家調查 : 偏 相関係数 $0.21, \mathrm{p}<0.05)$ 。この結果は，地点間の通信簿 の点差が大きいほど生物の群集構造の違いも大きく なることを示唆している。

\section{4. 社員調査と専門家調査の差異}

\section{（1）鳥類と昆虫類における差異}

鳥類と昆虫類について, 社員調査の発見種群数と 専門家調査の発見種群数（種数から変換）の関係を プロットしたのが図4である。昆虫類では $1: 1$ の直 線よりも上に分布が偏っているのに対し，鳥類では 1 : 1 の直線を中心に分布していることが分かる. 尤度比 検定の結果, 昆虫類では社員調査の発見種群数の方 が専門家調査の発見種群数よりも有意に大きかった $\left(\mathrm{X}^{2}=44.4, \mathrm{p}<0.05\right)$ が，鳥類では両者の間に有意差は なかった $\left(X^{2}=2.3, p>0.05\right)$. 同じ「種群」で比較した 場合，「目の数」の多い社員調査の種群数は専門家調 查の種群数より大きくなることが予想される，昆虫 ではこの予想と一致する結果が得られたにもかかわ
らず，鳥類ではほぼ 1:1の関係になったことは，社 員調查による鳥類相の把握能力が昆虫に比べて低い ことを示唆している.

\section{(2) 2 つの調査における差異の要因}

ピアソンの積率相関係数に対する $\mathrm{t}$ 検定の結果，社 員調査における各種群の発見率は, 社員調査におけ る個体数と正の相関があることが示唆された $(\mathrm{r}=0.245$, $\mathrm{t}=10.27, \mathrm{p}<0.05 ）$ が，バラツキは非常に大きくなって いた（図 5)。事実，発見率が 100\%であった種群につ いて，専門家調査での個体数を見てみると，実際に 個体数の多かった場合と個体数が少なかった場合と に明瞭に二極化していることが分かった（図 6)。こ のことは，発見率は必ずしも個体数を反映しないこ とを示唆している。また，専門家調査では個体数が 少なかった種群の内訳を見てみると，発見が容易か つ移動しない生物（クモ）や，発見が容易かつ一定 範囲を周回する生物（チョウ，トンボ），鳴き声から 定位が容易な生物（セミ）がその大半を占めていた。 このことから，社員調査の発見率は実際の個体数だ けでなく発見しやすさに大きく左右されることが分 かった。

\section{考察}

本研究では，生物多様性に貢献する緑地・土地利 用を評価する土地利用通信簿 ${ }^{\circledR}$ の点数と実際の生物多 様性に関係が見られるかどうか（課題(1)），そして生 物モニタリングシートによる調査でどの程度生物相 が把握できるのか（課題(2)，という2つを評価した。 まず課題(1)については, 土地利用通信簿 ${ }^{\circledR}$ の点数と $\alpha$ 多様性との間には説明率がおよそ $50 \%$ で正の関係が あり，さらに群集非類似度（ $\beta$ 多様性）と土地利用通 信簿 ${ }^{\circledR} の$ 点差との間にも社員調査で 0.32 ，専門家調査 で 0.21 の偏相関係数を持つ正の相関があったことか ら, 土地利用通信簿 ${ }^{\circledR} の$ 点数が企業所有地の生物の利 用場所としての価值を評価できていることが示唆さ れた（表 4, 図 2)。また同時に，土地利用通信簿 ${ }^{\circledR} の$ 評価内容や配点の妥当性を担保する結果と言える.

課題(2)については，専門家による調查との比較に より生物モニタリングシートを使った調查の性能を 評価した。 その結果， $\alpha$ 多様性についても $\beta$ 多様性に ついても社員調査と専門家調査には正の関係が認め られ，生物モニタリングシートを使った調査でも調 查地の生物相を把握できることが明らかになった。 このことは，簡易生物調査ツールとしての生物モニ 

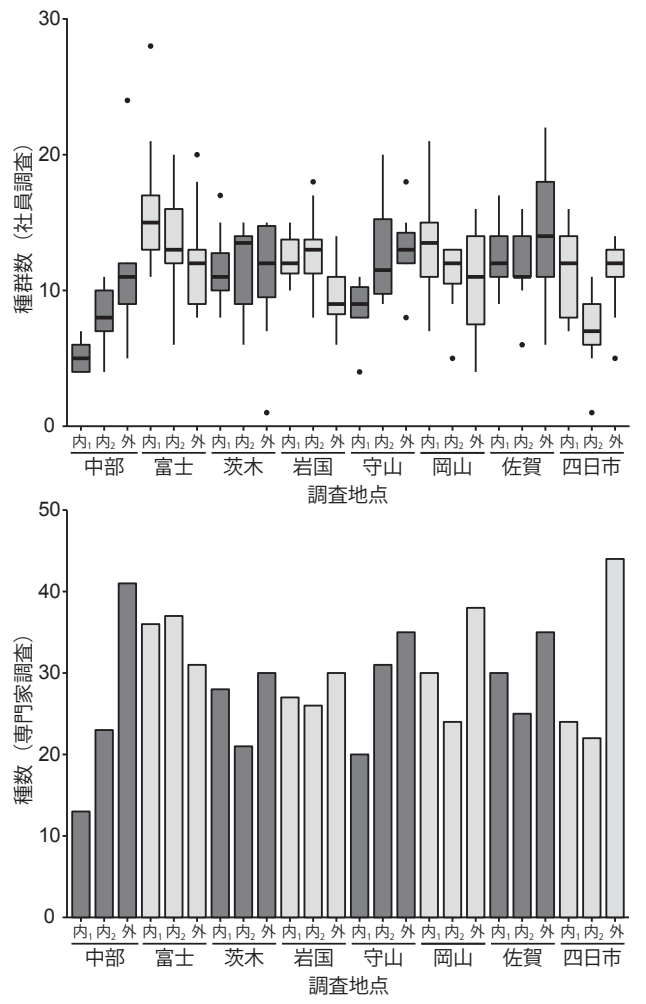

図 1. 各調查地点の発見種群数 (社員調査) および種数 (専 門家調查)。「内 $1 」\left\lceil 内_{2} 」\right.$ は事業所内の調査地点,「外」 は事業所外の調査地点を表す

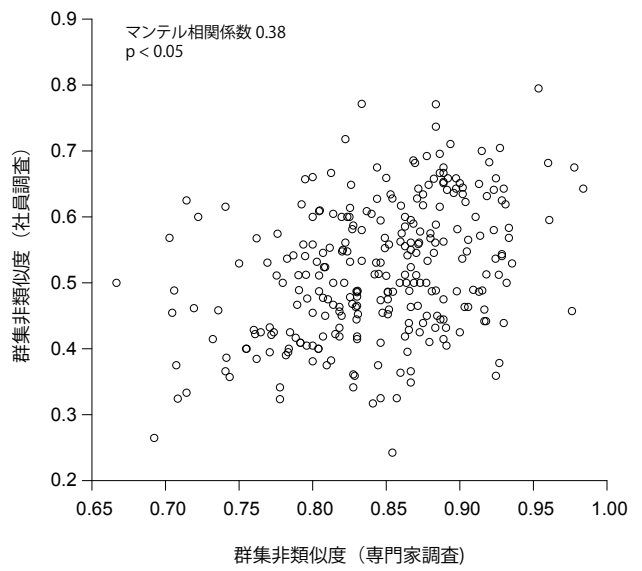

図 3. 専門家調查と社員調査の群集非類似度の関係。非類 似度は両者とも jaccard 指数.

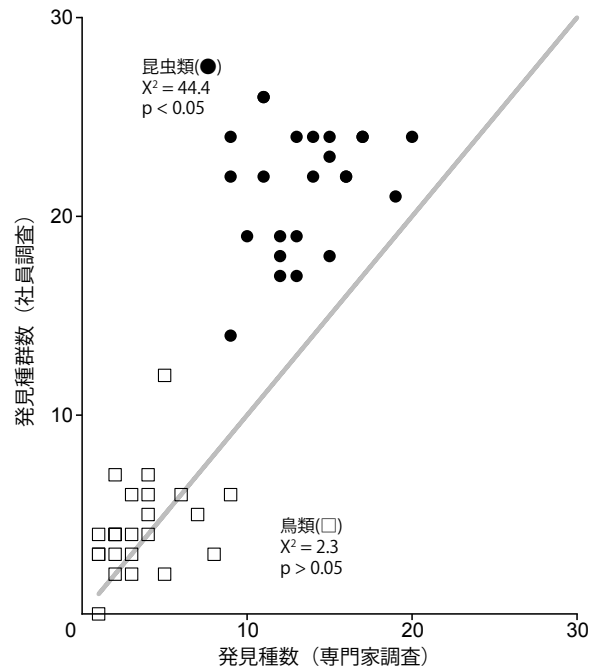

図 4. 昆虫類および鳥類の発見種群数の専門家調査と社員 調査の関係。
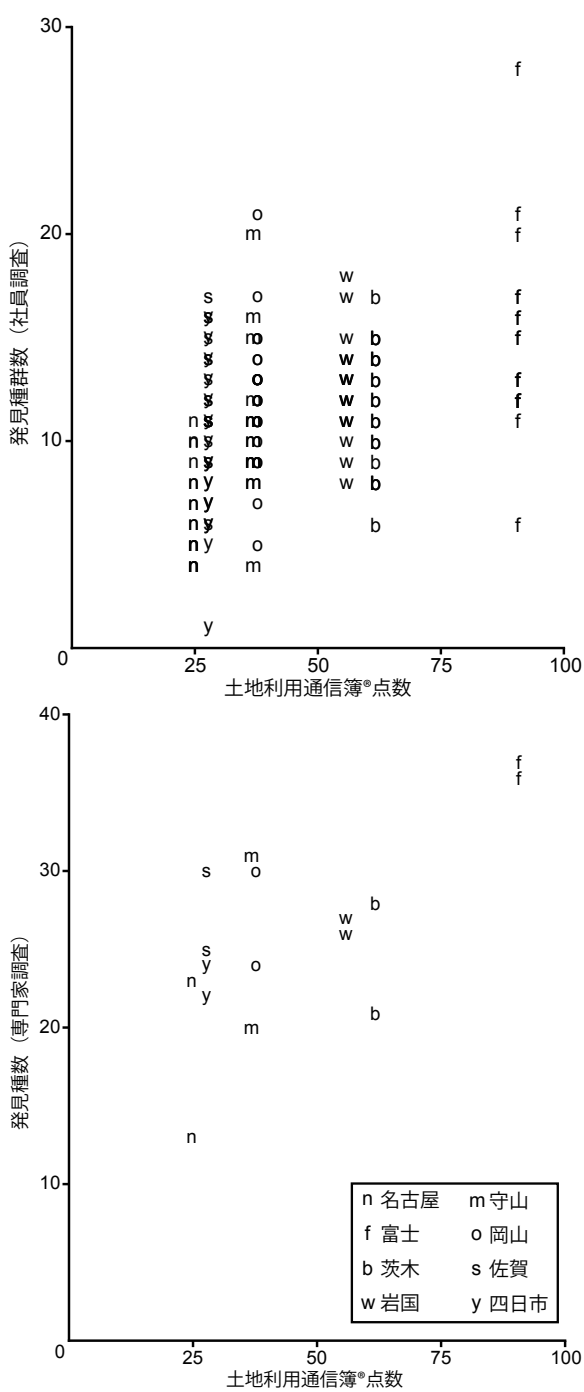

図 2. 土地利用通信簿 ${ }^{\circledR}$ の点数と (a) 発見種群数 (社員調查) または（b）発見種数（専門家調査）の関係。社員調 査のデータ点はそれぞれ調查員 1 人を表す.

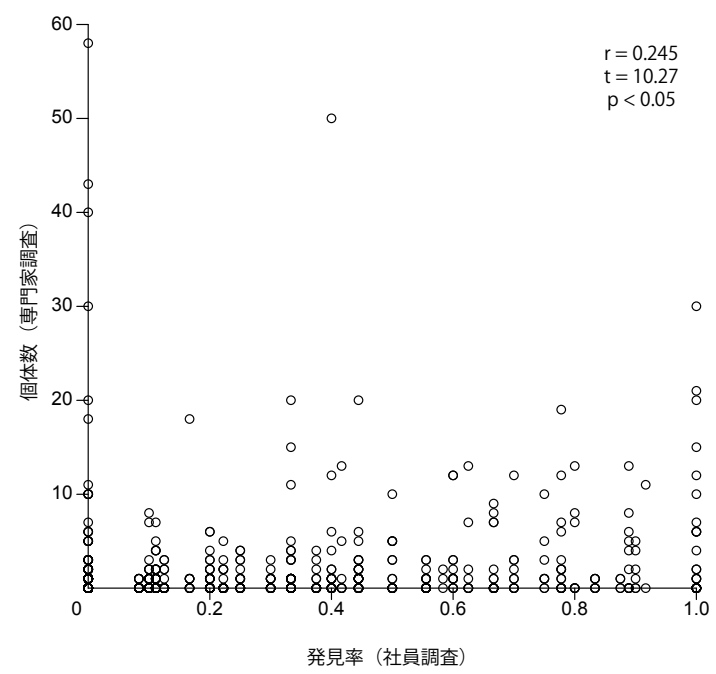

図 5. 各種群の発見率 (社員調查) と個体数（専門家調查） の関係. 


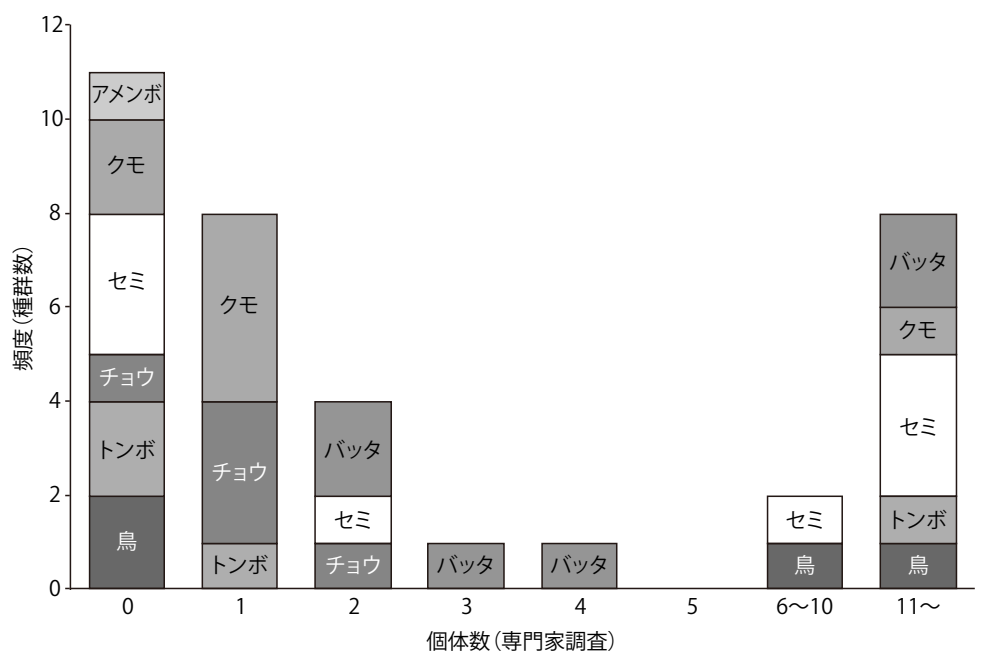

戝 6. 社員調查で発見率 $100 \%$ の種群における専門家調查 での個体数とその頻度（種群数）。

表 4. 発見種群数（社員調査）を応答変数とした GLMM のモデル選択により選択されたモデル．固定 効果の数值は係数を表す (ポアソン回帰). $* * *$ : $\mathrm{p}<0.001 ， * *: \mathrm{p}<0.01, *$ : $\mathrm{p}<0.05$. 第 5 位モデル の通信簿点数の計数は有意でないと判定されたが、 $\mathrm{p}$ 值は 0.061 であった。

\begin{tabular}{|c|c|c|c|c|c|c|c|c|c|c|}
\hline \multirow{2}{*}{$\begin{array}{l}\text { モデル } \\
\text { 順位 }\end{array}$} & \multirow[b]{2}{*}{ 切片 } & \multicolumn{6}{|c|}{ 固定効果 } & \multirow[b]{2}{*}{$\mathrm{df}$} & \multirow[b]{2}{*}{$\Delta \mathrm{AIC}$} & \multirow{2}{*}{$\begin{array}{c}\text { 逸脱度 } \\
\text { 説明率 } \\
(\%)\end{array}$} \\
\hline & & $\begin{array}{c}\text { 通信簿 } \\
\text { 点数 }\end{array}$ & 緑地率 & $\begin{array}{l}\text { 公園・ } \\
\text { 農地率 }\end{array}$ & $\begin{array}{c}\text { 市街地 } \\
\text { 率 }\end{array}$ & 水面率 & 気温 & & & \\
\hline 1 & $2.33^{* * * *}$ & $0.47^{* *}$ & & & $-0.26^{*}$ & & & 5 & 0.0 & 53.9 \\
\hline 2 & 2. $12^{\text {**** }}$ & $0.58^{* *}$ & & & & & & 4 & 0.7 & 53.1 \\
\hline 3 & 2. $32^{* * * *}$ & $0.40^{*}$ & & & -0.24 & 0.46 & & 6 & 0.9 & 54.2 \\
\hline 4 & 2. $11^{* * * *}$ & $0.47^{*}$ & & & & 0.64 & & 5 & 1.2 & 53.5 \\
\hline 5 & 2. $04^{* * *}$ & 0.36 & & 0.48 & & 0.70 & & 6 & 1.7 & 54.0 \\
\hline 6 & 2. $41^{* * * *}$ & $0.43^{*}$ & -0.14 & & -0.32 & & & 6 & 1.7 & 53.9 \\
\hline 7 & $1.99^{* * *}$ & $0.37^{*}$ & 0.28 & 0.51 & & 0.82 & & 7 & 1.8 & 54.5 \\
\hline 8 & 2. $06^{* * * *}$ & $0.48^{*}$ & 0.31 & & & 0.78 & & 6 & 2.0 & 53.9 \\
\hline 9 & $2.24^{* * * *}$ & $0.47^{\text {** }}$ & & & $-0.27^{*}$ & & 0.00 & 6 & 2.0 & 53.9 \\
\hline 10 & 2. $31^{* * * *}$ & $0.47^{\text {** }}$ & & 0.06 & -0.24 & & & 6 & 2.0 & 53.9 \\
\hline
\end{tabular}

表 5. 発見種数（専門家調査）を応答変数とした GLMM のモデル選択により選択されたモデル。固定 効果の数值は係数を表す (ポアソン回帰). $* * *: \mathrm{p}<0.001, * *: \mathrm{p}<0.01, *$ : $\mathrm{p}<0.05$. 第 7 位モデル の通信簿点数の計数は有意でないと判定されたが、 $\mathrm{p}$ 值は 0.063 であった。

\begin{tabular}{|c|c|c|c|c|c|c|c|c|c|c|}
\hline \multirow{2}{*}{$\begin{array}{c}\text { モデル } \\
\text { 順位 }\end{array}$} & \multirow[b]{2}{*}{ 切片 } & \multicolumn{6}{|c|}{ 固定効果 } & \multirow[b]{2}{*}{$\mathrm{df}$} & \multirow[b]{2}{*}{$\Delta \mathrm{AIC}$} & \multirow{2}{*}{$\begin{array}{c}\text { 逸脱度 } \\
\text { 説明率 } \\
(\%)\end{array}$} \\
\hline & & $\begin{array}{c}\text { 通信簿 } \\
\text { 点数 }\end{array}$ & 緑地率 & $\begin{array}{l}\text { 公園・ } \\
\text { 農地率 }\end{array}$ & 市街地率 & 水面率 & 気温 & & & \\
\hline 1 & $2.92^{* * * *}$ & $0.43^{*}$ & & 0.52 & & & & 3 & 0.0 & 49.9 \\
\hline 2 & 3. $00^{* * * *}$ & $0.5^{* * * *}$ & & & & & & 2 & 0.0 & 40.6 \\
\hline 3 & 3. $14^{* * * *}$ & $0.45^{*}$ & & & -0.18 & & & 3 & 0.7 & 46.8 \\
\hline 4 & 3. $39^{* * *}$ & $0.49^{*}$ & & & & & -0.01 & 3 & 1.6 & 42.4 \\
\hline 5 & $2.98^{\text {*** }}$ & $0.54^{\text {** }}$ & 0.13 & & & & & 3 & 1.7 & 41.9 \\
\hline 6 & 3. $21^{\text {*** }}$ & $0.41^{*}$ & & 0.50 & & & -0.01 & 4 & 1.8 & 50.9 \\
\hline 7 & 2. $91^{\text {*** }}$ & 0.38 & & 0.52 & & 0.26 & & 4 & 1.8 & 50.8 \\
\hline 8 & 3. $00^{\text {*** }}$ & $0.48^{*}$ & & & & 0.24 & & 3 & 1.8 & 41.4 \\
\hline 9 & 2. $91^{\text {*** }}$ & $0.44^{*}$ & 0.07 & 0.50 & & & & 4 & 1.9 & 50.3 \\
\hline 10 & $2.96^{\text {*** }}$ & $0.42^{*}$ & & 0.45 & -0.04 & & & 4 & 2.0 & 50.1 \\
\hline
\end{tabular}

表 6. 専門家調査の発見種数を応答変数とした GLMM のモデル選択の結果. 固定効果の数值は係数を 表す (ポアソン回帰). ***: $\mathrm{p}<0.001$

\begin{tabular}{|c|c|c|c|c|c|}
\hline \multirow[b]{2}{*}{ モデル順位 } & \multicolumn{3}{|c|}{ 固定効果 } & \multirow[b]{2}{*}{$\Delta \mathrm{AIC}$} & \multirow{2}{*}{$\begin{array}{c}\text { 逸脱度 } \\
\text { 説明率 } \\
(\%)\end{array}$} \\
\hline & 切片 & $\begin{array}{c}\text { 種数 } \\
\text { (社員調查) }\end{array}$ & $\mathrm{df}$ & & \\
\hline 1 & 2. $48^{* * * *}$ & $0.03^{* * * k}$ & 5 & 0.0 & 28.2 \\
\hline 2 & 3. $38^{* * * *}$ & & 4 & 13.5 & \\
\hline
\end{tabular}


タリングシートの有効性を示している. ただし $\alpha$ 多 様性の解析で選択されたモデルによる逸脱度の説明 率は $28.2 \%$ (表 6), $\beta$ 多様性のマンテル相関係数は 0.38 （図3）と高いとは言えなかった。 その対策として, 生物を探す際の見るべきポイント（例えば葉の裹や 木陰）など，種判別方法以外のトレーニングを事前 講習に盛り込むことや，今回の結果を利用して説明 率や相関係数が高くなるようにモニタリングシート のグループ分けを見直すことが考えられる.

一方で，生物モニタリングシートを使った調査の 問題点もいくつか見出された。まず，社員調査は鳥 類の把握能力が昆虫類に比べて低かった（図 4). こ れは社員と専門家の調査スキルの差が如実に現れた 結果と考えられる，というのも，専門家は例え姿が 見えなくとも鳴き声で鳥類を簡単に同定することが できるし，飛び立った時の一瞬のシルエットでも同 定できる場合があるからである。しかし，専門知識 が無ければこうしたケースでは種群を判別すること は困難である。したがって，生物モニタリングシー トは鳥類を調査するツールとしては昆虫類を対象に した場合に比べて性能が劣ると言える。ただし前述 のように鳥類の方が昆虫よりも高次レベルで種群に 分類されており，モニタリングシートに含まれる種 群の絶対数も少ないために, 社員調査と専門家調査 の差を検出しにくいという可能性も否定出来ない. 調查対象を絞ると記録可能な種群の総数が少なくな るため, 調査地間の差異を検出しにくくなる. 分類 群による調査能力の差異が認められつつも, 全体と しては通信簿点数や専門家調査の種数と正の関係が 認められたことも考慮すると，生物モニタリングシー 卜は，分類群を限定せずに様々な分類群を対象とし た調査に使用し，生物相の全体像を大まかに把握す るためのツールとして捉えるべきであろう。

次に, 生物モニタリングシートの発見率が必ずし も個体数を反映しておらず，生物量を把握するため のツールとしては不向きであることが示された（図 6). 発見率には発見しやすさが大きく関与している 可能性が大きかったことから，このシートはあくま で在・不在データを得るためのツールとして扱われ るべきであることが示唆された.

本研究では社員には業務時間中に調査を行っても らったため，時間上の制約などから社員による種群 同定の正確性を検証することができなかった。 しか し Fore et al. （2001） は淡水性の大型底生無脊椎動物 を対象に科レベルで同定したボランティアによる調
査データと, 属または種レベルで同定した専門家に よる調査データを比較したところ, 両者の $\alpha$ 多様性 の間には強い相関があり，また同定の正確性は $13 \%$ しか変わらなかったと報告している.また Kremen et al. (2011) は, 花粉媒介昆虫を対象に同様の比較を行っ たところ (ボランティアは目レベル), やはり専門家 調査との間に $\alpha$ 多様性について強い相関が見られた と報告している．生物モニタリングシートでは専門 知識がなくとも分かりやすい特徵を用いて科・目レ ベルでの種群分けを行っており，また事前講習を行 うなどの工夫を施しているため, 誤認率は低く抑え られていると考えられる.

また, おそらく最も重要なこととして, 種数や種 群数などの $\alpha$ 多様性は, 生物多様性の指標として広 く用いられているものの, その組成も合わせて把握 する必要があることは常に念頭に置いておくべきで ある。つまり $\alpha$ 多様性の大小だけでは, それが希少 種によるものなのか, 外来種によるものなのかを判 断することができない. 希少種や絶滅危惧種は時折 市街地に出現することがあり（Kendle and Forbes 1997 ; Godefroid 2001), 企業緑地がこうした生物の貴 重な生息場所になっている可能性がある. 実際に専 門家調査では，環境省の第 4 次レッドリストで準絶 滅危惧種に指定されているチュウサギやトノサマガ エルが企業緑地で見つかっている（環境省 2012）。地 域の希少種の保全活動として企業緑地を活用する取 組も広がりを見せており（服部 2007）, これを企業の CSR 活動の一環として組み込むこともできる.また 一方では侵略的外来種の巣窟になっている企業緑地 もあるかも知れない. 多くの工場では調整池が設置 されているが，それらにウシガエルやミシシッピア カミミガメが生息する可能性は十分にある.こうし た状況を見過ごさないために，生物モニタリングシー 卜による調查に加えて, 散発的にでも専門家による 調查を実施すべきであろう.

都市域では，もともとの生態系が大きく破壊され ているだけでなく, 都市に適応できた種のみ多くな る傾向が強い（McKinney 2006）。そのような種はたい てい移入種であるために都市域の生物相は従来とは 違った姿になっていることが多く, 都市に住む人々 はもともと生息していた在来種との触れ合いが減り, 結果として彼らの生物多様性や地域性への意識の向 上を妨げている（McKinney 2006）。人口密集地域にお ける地域の自然には，社会的・教育的な価值がある

(Miller and Hobbs 2002). 企業緑地を生物多様性が豊 
かな生態系にすることで，地域社会に新たな価值を 提供することにつながるかも知れない，いきもの共 生事業所 ${ }^{\circledR}$ 推進ツール 3 点セットには, こうした社会 貢献や環境コミュニケーションの意図も組み込まれ ている（企業と生物多様性イニシアティブ 2012）.

\section{結論}

土地利用通信簿 ${ }^{\circledR}$ の点数と $\alpha$ 多様性との間には正の 関係があることが示された。また専門知識のない調 査員による生物モニタリングシートを使った調査で も， $\alpha$ 多様性および $\beta$ 多様性という観点においては生 物相の把握が可能であることが示された。評価ツー ルとしての妥当性を裏付ける結果が得られたことは, 今後このツールをより多くの企業に普及させていく ための一つの成果と位置付けられるだろう。また今 後さらに調査を実施しデータを蓄積することで，土 地利用通信簿 ${ }^{\circledR}$ の点数配分のチューニングや生物モニ タリングシートの種群の分け方の改善などさらなる 改良が可能になるだろう。

\section{謝辞}

本研究を行うにあたりご協力頂いた皆様には心か ら御礼申し上げる。調査地となった各事業所職員の 皆様には調査のスムーズな進行にご協力頂いた。土 地利用通信簿 ${ }^{\circledR}$ を始め 3 つのツールを開発した下記 JBIB 持続的土地利用 WG のメンバーには本研究に 様々なご助言を頂いた：飯田慎一氏（パナソニック $($ 株)，伊藤俊哉氏（住友林業緑化(侏)，浦嶋裕子氏（三 井住友海上火琰保険(株)，木村幹子氏(対馬市)，久 保達哉氏（JSR (株)），杉本信幸氏（味の素(株)），瀬能靖 弘氏（凸版印刷(株)，高見謙氏（帝人(侏)，竹内和也 氏（三菱地所(株)，竹内恵子氏（株グリーン・ワイズ), 田畑真理氏（大阪ガス(株)，寺内孝夫氏（大日本印刷 (株)，永戸優子氏（凸版印刷(侏)，中村博一氏（大阪 ガス(株)，林豊氏（清水建設(株)，原口真氏（株インター リスク総研)，原田佳幸氏（イオンリテール(株)，平 井宗男氏 (旭化成(株) , 細見弘明氏 (旭化成(株)，本 名浩氏（帝人(株)，三宅茂氏（イオンリテール(株)，宮 本昌宏氏 (JSR (株) ) , 矢部明彦氏（富士ゼロックス(侏) (50 音順). 茨城大学の菊池佐智子氏および東北大学 の高野宏平氏には土地利用解析について貴重な助言 を頂いた。本研究は日本学術振興会グローバル COE プログラム J03 の助成を受けて行った.

\section{引用文献}

Arrhenius, O. 1921. Species and area. Journal of Ecology. 9: 95-99.

Baum, K. A., Haynes, K. J., Dillemuth, F. P. and Cronin, J. T. 2004. The matrix enhances the effectiveness of corridors and stepping stones. Ecology 85: 2671-2676.

Czech, B., Krausman, P. R. and Devers, P. K. 2000. Economic associations among causes of species endangerment in the United States. Bioscience 50: 593601

Fischer, J. and Lindenmayer, D. 2002. The conservation value of paddock trees for birds in a variegated landscape in southern New South Wales. 2. Paddock trees as stepping stones. Biodiversity Conservation 11: 833-849.

Fore, L. S., Paulsen, K. and O'Laughlin, K. 2001. Assessing the performance of volunteers in monitoring streams. Freshwater Biology 46: 109-123.

Godefroid, S. 2001. Temporal analysis of the Brussels flora as indicator for changing environmental quality. Landscape and Urban Planning 52: 203-224.

Haddad, N. M., Bowne, D. R., Cunningham, A., Danielson, B. J., Levey, D. J., Sargent, S. and Spira, T. 2003. Corridor use by diverse taxa. Ecology 84: 609615

服部保. 2007. 工場緑化と生物多様性 〜緑化の新し い視点〜．ビオトープ 19: 3-5

Kendle, T. and Forbes, S. 1997. Urban nature conservation: landscape management in the urban countryside. 352pp. E \& FN Spon, London.

環境省. 2012. 第 4 次レッドリスト. http://www. biodic.go.jp/rdb/rdb top.html

経済産業省地域経済産業グループ立地環境整備課。 2012. 工場立地法に関する最近の動向（特集 地域 環境と工場緑化)。グリーン・エージ 39: 16-19.

企業と生物多様性イニシアティブ．2012。いきもの 共生事業所 ${ }^{\circledR}$ 推進ガイドライン。第 2 版 $68 \mathrm{pp}$. 東 北大学生態適応グローバル COE.

Kremen, C. Ullmann, K. S., and Thorp, R. W. 2011. Evaluating the quality of citizen-scientist data on pollinator communities. Conservation Biology 25: 607617.

Luniak, M. 1994. The development of bird communities in new housing estates in Warsaw. Memorabilia 
Zoologica 49: 257-267.

Marzluff, J. M. 2001. Worldwide urbanization and its effects on birds. Avian Ecology in an Urbanizing World. (Marzluff, J. M., Bowman R. and Donnelly R. eds.), 1947. Kluwer, Norwell, MA.

McKinney, M. L. 2006. Urbanization as a major cause of biotic homogenization. Biological Conservation. 127: $247-260$.

Miller, J. R. and Hobbs, R. J. 2002. Conservation where people live and work. Conservation Biology. 16: 330337.

Murphy, H. T. and Lovett-Doust, J. 2004. Context and connectivity in plant metapopulations and landscape mosaics: does the matrix matter? Oikos 105: 3-14.

増澤直. 2010. 民間企業事業所緑地の生物多様性ポ テンシャル評価の試行. 日本緑化工学会誌 36 : 390-391.

三輪隆. 2011. 企業緑地の生物多様性評価と防災. 日本緑化工学会誌 37: 286-287.

宮下直・井鷺裕・千葉聡. 2012. 生物多様性と生態学: 遺伝子・種・生態系. $176 \mathrm{pp}$. 朝倉書店, 東京.

森本幸裕. 2011. 都市における生物多様性指標の開 発にあたって，日本緑化工学会誌 36: 367-368.

Mougi, A. and Kondoh, M. 2012. Diversity of interaction types and ecological community stability. Science. 337 : 349-351.

Prevedello, J. A. and Vieira, M. V. 2010. Does the type of matrix matter? A quantitative review of the evidence. Biodiversity and Conservation. 19:1205-1223.

R Development Core Team. 2013. R: a language and environment for statistical computing. Vienna, Austria.

Schultz, C. B. 1998. Dispersal behavior and its implications for reserve design in a rare oregon butterfly. Conservation Biology. 12: 284-292.

UNPD. 2007. World urbanization prospects: The 2007 revision. United Nations Population Division, New York. 